\title{
CRISPR/Cas9 trends and future scheme for genome engineering in plants
}

\section{Niroj Paudel ${ }^{1,2}$, Suhyong Park ${ }^{1 *}$, Yoonah Jang', Sherzod Rajametov ${ }^{1}$}

${ }^{1}$ National Institute of Horticultural and Herbal Science, Rural Development Administration, Wanju, 55365, Republic of Korea.

${ }^{1,2}$ Department of Applied Plant Science, Kangwon National University, Chuncheon 24341, Republic of Korea.

Email:

${ }^{1,2}$ Niroj Paudel : nirojjirauna@gmail.com

${ }^{1}$ Suhyoung Park: psh@korea.kr

${ }^{1}$ Yoonh Jang: limejya@korea.kr

${ }^{1}$ Sherzod Rajametov: sherzod_2004@list.ru

\section{*Corresponding Author}

Suhyoung Park

Email:psh@korea.kr

(Note: Niroj Paudel and Suhyoung Park has equal contribution) 


\begin{abstract}
The growing population meet the challenge for agricultural production. CRISPR/Cas9 technology is based on plant research for the development of the new varieties as well as disease resistance crops. In addition the deletion of significant characters makes the new alleles from the CRISPR/Cas9. Recent and reliable molecular scissor for genetic engineering. The review is focused on the various application of the CRISPR/Cas9 technology in plant enhancement of plant disease resistance, stress burden in plant, nutritional improvement, and quality of crops from the CRISPR/Cas9 system. The clustered regularly interspaced short palindromic repeat (CRISPR)associated protein9 (cas9) is adopted from the prokaryotic type II system. CRISPR/Cas9 is simplicity and efficiency than ZENs and TALENs for the genome engineering. Due to rapid growing of the CRISPR/Cas9 system has been formulate the adaptation of many plant species. The current advancement of plants and future schemes of improve of CRISPR technology has been presented in contest of multiplex editing, knowledge on induced mutation whether the factor effect in CRISPR/Cas9 technology in plant. Remarkable perspective and challenges of CRISPR/Cas9 technology in significance of plant genetic modification.
\end{abstract}

Keywords: CRISPR/Cas9, Disease resistance, Future perspective, Improvement of plants, Molecular scissor, Revolution 


\section{Introduction}

CRISPR/Cas9-based genome editing technology in the few years some problem still remains that happens influence of the targeted sites, chromatin structure, applied mechanism of the different guide RNA (gRNA)and path for the delivery in plants even Clustered Regularly Interspaced Short Palindromic Repeats/CRISPR associated proteins (CRISPR/Cas9) rapidly developed [1]. From the single guide RNA ( $\operatorname{sgRNA}$ ) as well as multiple guide RNA (mgRNA) the efficiency or the DNA modification for specific DNA sequence $[2,3,4]$. CRISPR technology have three types are type I, type II, type III for all type; type II embrace endonuclease,Cas9 which handle simple and easy for that cause Type II is strikingly used for the genome editing [2]. The genome adopt with CRISPR/cas9 can contemporary modify the multiple copies of the BnaFAD2 gene formulate the novel modification in fatty acids profile in polyploidy [5]. Genetic editing efficiency of CRISPR/Cas9 in Arbidopsis and Medicago trucatula [6].

Human population is increased rapidly to reach 10 billion by 2050 . Water are being reduced the available farmland, the global demand for food will increase by $25-70 \%$ above current production levels. In this case, feeding is going rapidly changeless. For that cause, an urgent need to improve food production and accelerate sustainable agricultural development [7]. CRISPR/Cas9 genome editing system can be improved to meet the demand of food scarcity. Instant of many crop species long life cycle, and the targeted genotype may be required for multiple generation. We have to applied breeding tool to generate the homogygous plant with in the generation whether the CRISPR/Cas9 is life changing technology which focus in the targeted gene and known as the genome editing that will help the development of the crops to meet the future demand [8]. The revolutionary technology is also in plant biology [9].

The rapid genome sequencing technology requires the transfer of the potential to create the the desirable modification of the functional and regulatory mechanism. Specific genome sequencing facilitate the understanding of the biological system. Such technologies depend on sequence-specific nucleases (SSNs) and molecular tools used to generate DNA double-strand breaks. For the genetic variation 
of the plant is the key factors to adopt the different environmental conditions and higher yield. Which will be control on the disease mechanism. The CRISPR/Cas based frameworks have opened the new time of molecular biology and become the most reliable technology among researchers for altering and changing genome in across the board creatures particularly plants [10]. Clustered Regularly Interspaced Short Palindromic Repeats - CRISPR associated protein Cas9 genomeediting technique modify by the researcher for genome sequencing is more valuable [11].

From prokaryotic organism (a sort II bacterial resistant framework) that follows up on a changeable invulnerable framework, the CRISPR/Cas9 innovation is advanced and in this way shields these living beings from attacking DNA infections which is caused by the plasmid. The potential pesticide use to connect the broadly to about the life from of the practical use in CRISPR/Cas9, site - explicit change accompanied by the guide RNA (around 20 nucleotides). Twofold strand breaks (DSBs), which is caused by the Cas9 nuclease at the point of the targeted DNA site. The powerful tool CRISPR/Cas9 which enhancement of agronomic traits in crops [12] Efficient gene editing in plants through either transient experiment or transgenic plants which is recently remarkable used CRISPR/Cas9 technology. In many experimental application of gRNAs and Cas9 introduce inside the plant cells by Agrobacterium-mediated T-DNA transformation or physical means, such as PEG-mediated transformation of protoplast, and microspore or biolistic transformation of callus. Cas proteins, such as Cas9, are RNA- directed endonucleases which are able to recognize and cleave nucleic acids on the basis of sequence complementarities [13]. For the specific DNA genomic sequences by engineering separately an encoded small guide RNA (sgRNA) with which it forms a complex by the Cas9 whether the short RNA sequence is the best for new target site of DNA. 
CRISPR/Cas9 technology is simple and flexible tool for RNA guided genome editing (RGE) in an organism. In case of Cas 9 medicated RGE, RNA molecules directs to desire the targeted DNA site for genome modification. In presence of prtospacer adjacent motif (PAM) in target site gRNA-DNA pairing the region. PAM is exchange the long 20 chain gRNA spacer sequence. Complexes of gRNA/Cas9 need to the PAM site which matched gRNA space which is the result of risk of gene editing. Gene editing used for the meristem tip culture and noted the gene editing reagent for the delivery to the somatic cells [14]. Improvement of crop cultivar from higher productivity standpoint is a major challenge gains the pest and diseases. The major reason farmers are facing loss in agriculture production because lack of disease resistance crops. Cultivars safeguarding food security for the plant breeding for pest, disease resistance and higher yield. The various genome editing instrument for the transgenic plants integrated the plant breeding to improve the resistance pest and disease. For the transgenic technology which allow the plant breeder to introduce the gene for the non-related plants, and other crops [15]

The variation of gene is initial factor for the resistance breeding, which the concept of the resistance breeding creation of the genetic variation with against the resistance pathogen [16]. In the incident of the facts, the editing technology has been introduced the varieties or modification of the plants and crops. One of the recent breakthrough is CRISPR (Clustered Regular Interspaced Palindromic Repeats)/Cas9. (CRISPR- associated protein) bacterial immune system which is RNA-guided instrument for and gene regulation and beneficial gene editing [17].

Zinc Finger Nucleases (ZFNs) and Transcription Activator Like Effector Nucleases (TALENS) however, they are less suitable as compared to CRISPR/Cas9 because of large size and requirement of a pair of proteins for recognizing anti parallel strands to induce double strands 
Break [10]. Desirable features like precise specificity, multi gene editing, minimal off-target effects, higher efficiency and simplicity in CRISPR/Cas9 [17]. The CRISPR/Cas9 technology in bacteria acquire invading or foreign DNA fragments and utilize them to recognize and degrade the further invading sequence for RNA or DNA. Defensive mechanism in plants against disease attack by recognizing and degrading the invading pathogenic genes CRISPR/Cas9 can be used. CRISR/Cas9 is better for the development of disease resistance cultivar, and it proves the revolution in resistance breeding. The aims of review to give the information in current advances in CRISPR/Cas9 and its use in resistance breeding.

Table 1. CRISPR/ Cas9 system and its Classification [18,19]

\begin{tabular}{|c|c|c|c|c|c|}
\hline Class & Type & $\begin{array}{l}\text { Sub- } \\
\text { type }\end{array}$ & $\begin{array}{l}\text { Organism harboring respective } \\
\text { type }\end{array}$ & $\begin{array}{l}\text { Signature of Cas } \\
\text { proteins }\end{array}$ & Other Core Protein \\
\hline \multirow{16}{*}{$\begin{array}{l}\text { Class } \\
1\end{array}$} & \multirow{10}{*}{ I } & & & & Cas1, Cas2, Cas5, \\
\hline & & $\mathrm{I}-\mathrm{A}$ & Archaeoglobus fulgidus & Cas3, Cas8 & Cas6, Cas7 \\
\hline & & & & & Cas1, Cas2, Cas5, \\
\hline & & $\mathrm{I}-\mathrm{B}$ & Clostridium kluyveri & Cas3, Cas8 & Cas6, Cas7 \\
\hline & & & & & Cas1, Cas2, Cas5, \\
\hline & & $\mathrm{I}-\mathrm{C}$ & Bacillus halodurans & Cas3, Cas8 & $\begin{array}{l}\text { Cas7 } \\
\text { Cas1 Cas2 Cas5 }\end{array}$ \\
\hline & & $\mathrm{I}-\mathrm{D}$ & Cyanothece sp. & Cas3, Cas 10 & Cas6, Cas7 \\
\hline & & $\mathrm{I}-\mathrm{E}$ & Escherichia coli & Cas3, Cas8 & $\begin{array}{l}\text { Cas1, Cas2, Cas5, } \\
\text { Cas7 }\end{array}$ \\
\hline & & $\mathrm{I}-\mathrm{F}$ & Yersinia pseudotuberculosis & Cas3, Cas8 & $\begin{array}{l}\text { Cas1, Cas2, Cas5, } \\
\text { Cas6, Cas7 } \\
\text { Cas1, Cas2, Cas5, }\end{array}$ \\
\hline & & $\mathrm{I}-\mathrm{U}$ & Geobacter sulfurreducens & Cas3, Cas8 & Cas6, Cas7 \\
\hline & \multirow[t]{5}{*}{ III } & III-A & Staphylococcus epidermidis & Cas10 & $\begin{array}{l}\text { Cas1, Cas2, Cas5, } \\
\text { Cas6, Cas7 }\end{array}$ \\
\hline & & & & & Cas1, Cas2, Cas5, \\
\hline & & III-B & $\begin{array}{l}\text { Pyrococcus furiosus } \\
\text { Methanothermobacter }\end{array}$ & Cas10 & Cas6, Cas7 \\
\hline & & III-C & thermaautotrophicus & Cas10 & Cas5, Cas7 \\
\hline & & III-D & Roseiflexus sp. & Cas 10 & Cas5,Cas7 \\
\hline & IV & IV & Acidithiobacillus ferrooxidans & Casf1 & Cas5,Cas7 \\
\hline \multicolumn{6}{|l|}{ Class } \\
\hline \multirow[t]{5}{*}{2} & \multirow[t]{3}{*}{ II } & II-A & Streptococcus thermophilus & Cas9 & Cas5, Cas7 \\
\hline & & II-B & Legionella pneumophila & Cas9 & Cas1, Cas2 \\
\hline & & II-C & Neisseria lactamica & Cas9 & Cas1, Cas2 \\
\hline & $\mathrm{V}$ & $\mathrm{V}$ & Francisella cf. novicida & Cpf1 & Cas1, Cas2 \\
\hline & $\mathrm{VI}$ & VI & Leptotrichia shahii & $\mathrm{c} 2 \mathrm{c} 2$ & Cas1, Cas2 \\
\hline
\end{tabular}




\section{Mechanism of CRISPR/Cas9}

The Cas9 protein and guide RNA, form a complex that can recognize target sequences. The Cas9 protein locates and cleaves target DNA, in artificial CRISPR/Cas9 systems. The Cas9 protein is having six domains (REC I, REC II, Bridge Helix, PAM Interacting, HNH and RuvC). The Rec I domain is responsible for binding the guide RNA. The bridge helix which is argininerich initiates the cleavage after binding of target DNA. The PAM (Protospacer adjacent motif) domain specifies the PAM specificity and initiates binding to target DNA. The HNH and RuvC domains are nuclease domains that cut single-stranded DNA. The Cas9 protein initially inactive when not attached to gRNAs. For the CRISPR technology, guide RNA is composed of a single strand RNA which is a T-shape ( 1 tetraloop and 2 or 3 stem loops). For the complimentary to the target DNA sequence the guide RNA having a 5'. Cas9 protein converts the inactive into its active form by inducing a conformational change in the protein which includes steric interactions or weak binding between protein side chains and RNA bases in case of artificial guide RNA. For the PAM sequence, the activated Cas9 protein searches for target DNA. The protein will melt the bases immediately upstream of the PAM and pair them with the complementary region on the guide RNA. After that the $R u v C$ and $H N H$ nuclease domains cut the target DNA in case of the exact target sequence.

The former guiding to target recognition on genome to cut double-stranded DNA sitepointy are two important components that are present in CRISPR/Cas9 system, which are sgRNA and DNA endonuclease Cas9. The Watson-Crick base pairing between the guiding sequence and the DNA Cas9/sgRNA complex recognize the complimentary loci in the genome sequencing. The target region is induced, due to specific changes are performed by Cas9, forming two nuclease domains $[20,21]$. After that, the nuclease domains cut both strands of the target DNA, located at 
almost 3 nucleotides in front of proto-spacer adjacent motif (PAM), resulting with the inducing of double strand breaks (DSBs) [22].

\subsection{CRISPR/Cas9 for gene manipulation and gene editing}

Interesting topic for research works in molecular biology and plant breeding are gene editing and gene manipulation. The expression of specific genes to obtain desirable traits and characters in an organism and has high use in breeding of disease resistant and higher yielding cultivars from the gene regulation. The gene editing is used to produce the highly used transgenic plants to know and examine the new resistance gene against the pest and disease of the crops. For the new transgenic plants all gene editing technology has been used for the plant genetic engineering. Various concepts for gene editing and gene manipulation serve as important tools for plant breeders and the molecular biologist to essential genes in genomes of important crops [17]. The key for gene editing consists of binding domain and effector domain. Binding domain and bind of sequence specific DNA while effector domain helps cleavage of DNA at target site and regulates transcription [23]. CRISPR locus or array are located on the genome and consists of hyper variable spacers acquired from bacteriophage virus or plasmid DNA in CRISPR/Cas9, and Cas genes are located upstream of CRISPR loci and encodes for Cas protein for defense of invasive genetic materials [24].

Foreign nucleic acid and acquire small fragments of DNA from invading bacteriophages and plasmids contain in CRISPR. The host incorporates the acquired fragments into its CRISPR locus as spacers between short DNA repeats. A short stretch of conserved nucleotides, Protospacer Adjacent Motifs (PAMS) act as recognition motif for the acquisition of DNA fragment into the spacer [17]. The expression of Cas proteins then transcribes the spacers acquired CRISPR to form pre CRIPSR RNAs (pre-crRNAs) which after cleavage and maturation of pre crRNAs results into 
CRISPR RNAs (crRNAs). These crRNAs contains spacer sequence from previous foreign nucleic acid that helps in the recognition and cleavage of invading genome, which matches with the spacer sequence and helps to protect the host cells [23]. The ability of bacteria to acquire invading or foreign DNA fragments and utilize them to degrade further invading DNA or RNA sequences confers CRISPR/Cas9 system as an acquired and heritable defense system [24].

Specific sequence of bacterial DNA can be edited and invading foreign DNA with the use of sgRNA such as phages can be cleaved by RNA guided nuclease in a sequence specific manner [25]. For sgRNA wich binds the DNA and pre- design sequence in RNA guided Cas9 enzyme to cut the DNA strand at specific loci for cutting of DNA proceeds with removal and addition of required sequences into the target DNA [23]. The instrument can be through delivery of sgRNA and Cas9 into target cells for gene transformation for create the resistance specific disease plants.

For delivery of sgRNA and Cas9 into plants cells like electroporation, via plasmids, agrobacterium mediated transformation, shotgun methods, particle bombardment and polyethylene glycol mediated transformation can be used [26]. However, easy and commonly used in many experiments is Agrobacterium medicated gene transformation [27, 28, 29]. Efficacy of CRISPR/Cas9 against tomato yellow leaf curl virus (TYLCV) in Nicotiana benthamiana plants and found exhibited profound evidence of interference against viral DNA by use of guide RNA mediated through Agrobacterium tumefaciens engineered tobacco rattle virus (TRV) with sgRNA specific for TYLCV into Agrobacterium tumefaciens and infiltrated it into plant [27] .

CRISPR/Cas9 instrument integrated with Agrobacterium mediated gene transformation was applied in Nicotiana benthamiana and Arabidopsis thaliana against beet severe curly top virus similar finding was observed [29]. Interference of Cas9/sgRNA by binding to viral genetic element prevents replication of viral gene by blocking access of viral gene to replication protein 
or by cutting double stranded DNA of virus to cease its replication or by causing error prone mutation of viral genome and the sgRNA also control viral DNA whose matches sequence [27]. Specific DNA target and by using variable crRNAs it is possible to design multi target sgRNAs which requlates the crRNA sequence [17].

\subsection{Gene altering from CRISPR/Cas9}

The potential for considerable improvement over other quality altering advances which offers the most dependable and flexible stage to design plant genome from the CRISPR/Cas9. Fabulous application in animal science which is turned to change in plant science for the multipurpose [30].

Initially, CRISPR/Cas instrument was regulated by the bacterial type-II CRISPR/Cas adaptive immune system that is the hosts to cleave invading phage or plasmid DNA [31]. For the capacity of CRISPR/Cas9 framework a protospacer-containing CRISPR RNA (crRNA), a transactuating crRNA (tracrRNA) and a Cas9 endonuclease. Specially,

Cas9 nuclease is pointed by the crRNA and tracrRNA duplex to divide the trespassing DNA conveying the similar protospacer partitions is accompanied by a protospacer adjoining theme (PAM). The PAM is completely main role as it conveys the foundation of the crRNA tracrRNA/Cas9 unidentified and definite furthermore progressive base blending between the crRNA and the protospacer [32].

\subsection{Off-targeting and specificity of CRISPR/Cas9}

Target mechanism is considerable and implication of genome editing which is valuable for the specific target site. In case of plant, target site is more specific and less effect in most of the species. In most species unlinked mutation has been occurred performing backcross to untransformed plants. The complement of the guide sequence of the sgRNA and the DNA targetis 
specified by the CRISPR/Cas9. Bioinformatics tools can be applied for minimize the off-targeting and increase the specificity of sgRNA [10].

\section{CRISPR/Cas9 as gene editing instrument in plants}

Deletion and insertion which is single point of several groups in particular gene in sgRNA for the repair gRNA directed to Cas9 nucleases which also be applied for the induced large genomic rearrangement or deletion such as inversion or translocation.

NHEJ (Non Homologous End Joining) gene knock out in organisms including plants is the main application of CRISPR/Cas9.

Cas9 and sgRNA instrument for the various combinations to find the transit expression in Arabidopsis, tobacco, rice and sorghum using Agrobacterium or PEG mediated transformation [26]. For finding the function of the enzyme genes and expression of miRNASs NHEJ-mediated CRISPR/Cas9 is a suitable technology. Highly desirable repair(HDR) pathway for the double standard break (DSB) focus on gene knock in replacement of gene in plant genome is successfully conduct in tobacco [36].

\section{Application of CRISPR/Cas9 technology}

\subsection{Validity of CRISPR/Cas9 in resistance breeding in plants}

The urgent need of efficient crop improvement schemes with advanced and reliable gene editing tools is CRISPR/Cas9 [33]. DNA with removal of target sequence and addition of gene of interest by creating the mutation from the CRISPR/Cas9 technology. Benefits of CRISPR/Cas are multi gene editing, mutagenesis in inaccessible gene and gene deletion of large generated gene which ultimately used to progressive for plant breeding [34].The modification I of plant genome 
be inherited stable, and Cas9/sgRNA and the successive formation of the crops variation in further generation [35]. The pre calculated sequences in RNA guides Cas9 enzyme for the DNA strands at exact locations guide RNA can be bind in DNA sequence.

Induces mutations and the cut DNA is repaired from the DNA recombination. Instant, unwanted mutation is not necessary for the 20 base pair in sgRNA sequence need to be complimentary base pair whether the results will be falls. In falls mutation and DNA essential sequence information will be lost. Most of the researcher are working to make use accuracy of CRIPSR/Cas9 as Cas9 enzyme can be regulated to target different sites by changing the sequence in sgRNA for the DNA [23].

\subsection{CRISPR/Cas9 for antiviral resistance in plants}

Protection from infections in a few harvest plants CRISPR/Cas arrangement of genome altering has now been utilized proficiently a technology [25]. The records have been reported which CRISPR/Cas widely utility for the preservation of gemiviruses [29]. For the preserve and protection of the plant against the gemiviruses species represents the BCTV (Beet wavy top infection), TYLCV (Tomato yellow leaf twist infection), and MeMV (Merremia mosaic infection). For the specific acquisition, expression, and impedance CRISPR/Cas9 technology first implication for the particular site of DNA of attacking pathogens.

The specific pioneer side of the CRISPR locus which duplication and joining the repair the DNA is a principle methods. In instant short part of DNA fused by means of CRISPR in bacterial genome and makes another spacer arrangement. Long pre-CRISPR RNA (pre-crRNA) then actively proceeds in crRNAs with the help of specific Cas protein as well as trans activating crRNA (tracRNA). For the final situation as interference, foreign gene element is targeted and cleaved 
into small fragments for a specific sequence. The complimentary target region of DNA of viruses and plasmids, and induction of resistance plants from the crRNA directs the Cas9 protein [17].

\subsection{CRISPR/Cas9 for contraction in plants opposed to bacterial and fungal components}

Most severe diseases affecting plants, leading to significant reduction in yield and crop quality cause economic loss in worldwide from the fungal pathogen [37]. In application of CRISPR/cas9 to manage the plant virus also help to the versatile path for the fungal as well as bacterial pathogens. Burkholderia glumae, Burkholderia gladioli, and Burkholderia plantarii are the rice pathogenic bacteria which causes the seedling blight, sheath rot grain rot so on can reduce the rice production for minimize the biological control tool [21].

B. plantarii ATCC 43733T has related features B. glumae and B. gladioli, but this $B$. plantarii strain CRISPR/CRISPR-associated protein (Cas) systems, signifying that B. glumae has evolved rapidly or has undergone rapid genome rearrangements or deletions in response to the host plants Burkholderia species has distingused charecters comparision to the other Burkholderia species of humans animals and plants [38]. Efficiently disrupt target genes in the smut causing maize pathogen Ustilago maydis type II bacterial CRISPR/Cas9 system has been used

Successfully to target the mildew-resistance locus O (MLO) in wheat, generating plants resistant to powdery mildew disease from the CRSPR/Cas9 [39]. The ethylene pathway in rice was successfully modified by targeting a mutation in OsERF922 using CRISPR/Cas9 technology to increase resistance to rice blast pathogen caused by Magnaporthe oryzae [23].

For mlo-type resistance against powdery mildew and other pathogen CRISPR/cas system can be applied and hold the potential type. Richter et al. [40] Pectobacterium atrosepticum, a plant pathogen that causes soft-rot and blackleg disease in potato has been formation of protein - 
protein interaction complex formation in the subtype I-F CRISPR/ Cas system including Cas1, Cas3, and the four subtype specific proteins Csy1, Csy2, Csy3 and Cas6. Research on of citrus gene function and for targeted genetic modification [41].

Table2. CRISPR/Cas9 Application in some valuable plants

\begin{tabular}{|c|c|c|c|c|}
\hline Name of Plants & Gene of Plants & Purpose for editing & Benefit for editing & References \\
\hline Oryza sativa $\mathrm{L}$. & $\begin{array}{l}\text { OsSWEET11, } \\
\text { OsSWEET14 } \\
\text { (rice bacterial blight } \\
\text { Susceptibility) }\end{array}$ & $\begin{array}{l}\text { For the resist against } \\
\text { Bacterial } \\
\text { blight of rice against } \\
\text { Xanthomonas oryzae. }\end{array}$ & $\begin{array}{l}\text { PEG stimulated } \\
\text { Cas9/sgRNA uptake } \\
\text { of gene in rice } \\
\text { protoplast }\end{array}$ & [26] \\
\hline Oryza sativa L. & TMS5 & $\begin{array}{l}\text { To develop commercial } \\
\text { 'transgene clean'TMGES } \\
\text { rice lines. }\end{array}$ & $\begin{array}{l}\text { Offspring's were } \\
\text { observed to be } \\
\text { healthier and } \\
\text { provided a more } \\
\text { benefit yield } \\
\text { compared with the } \\
\text { control. }\end{array}$ & [42] \\
\hline Oryza sativa $\mathrm{L}$. & $\begin{array}{l}\text { OsERF922 } \\
\text { (ethyleneresponsive } \\
\text { factor transcription } \\
\text { factor) }\end{array}$ & $\begin{array}{l}\text { To fight against Rice } \\
\text { blast } \\
\text { disease caused by } \\
\text { Magnaporthe oryzae }\end{array}$ & $\begin{array}{l}42 \% \text { T0 mutant lines; } \\
6 \text { T2 homozygous } \\
\text { mutants showed high } \\
\text { blast resistance and } \\
\text { had the same } \\
\text { agronomic traits }\end{array}$ & [39] \\
\hline (Oryza sativa $\mathrm{L}$. & $A L S$ & $\begin{array}{l}\text { To introduce various } \\
\text { distinct point mutations } \\
\text { in } \\
\text { the rice ALS gene. To } \\
\text { increase resistance } \\
\text { against herbicide. }\end{array}$ & $\begin{array}{l}\text { Knock-in and } \\
\text { resistant against } \\
\text { sulfonylurea } \\
\text { herbicides }\end{array}$ & {$[43]$} \\
\hline $\begin{array}{l}\text { Triticum } \\
\text { aestivum } \mathrm{L} .\end{array}$ & TaMLO homologs & $\begin{array}{l}\text { To increase resistance } \\
\text { against powdery mildew } \\
\text { in } \\
\text { wheat. }\end{array}$ & $\begin{array}{l}\text { Knockout and } \\
\text { resistance to powdery } \\
\text { mildew }\end{array}$ & [39] \\
\hline $\begin{array}{l}\text { Triticum } \\
\text { aestivum } \mathrm{L} .\end{array}$ & $T a G W 2$ & $\begin{array}{l}\text { For efficient and specific } \\
\text { genome editing }\end{array}$ & $\begin{array}{l}\text { TaGW2 gene plays a } \\
\text { vital role in } \\
\text { grain weight control. }\end{array}$ & [44] \\
\hline $\begin{array}{l}\text { Gossypium } \\
\text { hirsutum L. }\end{array}$ & $\begin{array}{l}\text { GhCLA1 } \\
\text { (Chloroplasts } \\
\text { alterados 1) }\end{array}$ & $\begin{array}{l}\text { For targeted mutagenesis } \\
\text { of the cotton } \\
\text { genome }\end{array}$ & $\begin{array}{l}\text { Mutations were } \\
\text { detected in cotton } \\
\text { protoplast. }\end{array}$ & [45] \\
\hline G. hirsutum L. & $\begin{array}{l}\text { An endogenous gene } \\
\text { GhCLA1 } \\
\text { and DsRed2 } \\
\text { (Discosoma red } \\
\text { fluorescent protein2) }\end{array}$ & $\begin{array}{l}\text { For targeted mutagenesis } \\
\text { of the cotton } \\
\text { genome }\end{array}$ & $\begin{array}{l}\text { Disappeared red } \\
\text { fluorescence and } \\
\text { showed the albino } \\
\text { phenotype }\end{array}$ & [46] \\
\hline G. hirsutum L. & GhMYB 25- & $\begin{array}{l}\text { For efficient and specific } \\
\text { genome editing }\end{array}$ & $\begin{array}{l}G h M Y B 25 \text {-like } \\
\text { involved in the }\end{array}$ & [47] \\
\hline
\end{tabular}


establish of cotton

fiber.

\begin{tabular}{|c|c|c|c|c|}
\hline Zea mays L. & $\begin{array}{l}\text { ZmAgol8a and } \\
\text { ZmAgo18b } \\
\text { unless (a1 and a4) } \\
\text { (Argonaute } \\
\text { 18) and reductase or } \\
\text { anthocyanins (a1 and } \\
\text { a4) }\end{array}$ & $\begin{array}{l}\text { For mutagenesis } \\
\text { frequency and heritability }\end{array}$ & $\begin{array}{l}\text { Involved in the } \\
\text { biosynthesis of 24- nt } \\
\text { phase RNA in anthers }\end{array}$ & [48] \\
\hline $\begin{array}{l}\text { Glycine } \\
\text { L.Merr. }\end{array}$ & $\begin{array}{l}\text { GmPPD1 } \\
\text { GmPPD2 }\end{array}$ & $\begin{array}{l}\text { Inheritable site-directed } \\
\text { mutagenesis }\end{array}$ & $\begin{array}{l}\text { Trifoliate leaves were } \\
\text { observed } \\
\text { thicker with deeper } \\
\text { green color, } \\
\text { longer petioles, and } \\
\text { more giant pods }\end{array}$ & [49] \\
\hline $\begin{array}{l}\text { Glycine } \quad \max \\
\text { L.Merr.) }\end{array}$ & GmFT2a & $\begin{array}{l}\text { To induce targeted } \\
\text { mutagenesis of GmFT2a }\end{array}$ & $\begin{array}{l}\text { Showed late } \\
\text { flowering under both } \\
\text { short-day and long- } \\
\text { day conditio }\end{array}$ & {$[50]$} \\
\hline $\begin{array}{l}\text { Sorghum bicolor } \\
\text { L. Moench) }\end{array}$ & $\begin{array}{l}\text { Whole } k 1 C \text { gene } \\
\text { family }\end{array}$ & $\begin{array}{l}\text { For create kafirin variants } \\
\text { for the improvement of } \\
\text { protein quality } \\
\text { digestibility }\end{array}$ & $\begin{array}{l}\text { Vitreousness and a- } \\
\text { kafirin levels } \\
\text { were reduced, } \\
\text { whereas an increase } \\
\text { in the grain protein } \\
\text { digestibility and } \\
\text { lysine content was } \\
\text { observed akafirin } \\
\text { were observed. }\end{array}$ & [51] \\
\hline $\begin{array}{l}\text { Hordeum vulgare } \\
\text { L. }\end{array}$ & HvPM19 & $\begin{array}{l}\text { For induce targeted } \\
\text { mutagenesis of barley } \\
\text { genes. }\end{array}$ & Dwarf phenotype & {$[52]$} \\
\hline $\begin{array}{l}\text { Brassica } \\
\text { oleracea }\end{array}$ & BolC.GA4.a & $\begin{array}{l}\text { For induce targeted } \\
\text { mutagenesis of } B . \\
\text { oleracea genes. }\end{array}$ & Dwarf phenotype & {$[52]$} \\
\hline Brassica napus L. & $\begin{array}{l}\text { RGAs, FULs, DAs, } \\
\text { and A2.DA2 }\end{array}$ & $\begin{array}{l}\text { For induce targeted } \\
\text { genome modifications at } \\
\text { multiple loci }\end{array}$ & Dwarf phenotype & [53] \\
\hline B. napus L. & $\begin{array}{l}\text { Rapeseed } \quad \text { SPL3 } \\
\text { homologous } \\
\text { gene copies }\end{array}$ & $\begin{array}{l}\text { For rapidly generate and } \\
\text { identify mutagenesis of } \\
\text { multiple gene homologs } \\
\text { Simultaneously. }\end{array}$ & $\begin{array}{l}\text { Showed } \\
\text { developmental delay } \\
\text { phenotype }\end{array}$ & {$[54]$} \\
\hline $\begin{array}{l}\text { Manihot } \\
\text { esculenta }\end{array}$ & $\begin{array}{l}\text { MePDS (phytoene } \\
\text { desaturase) } \\
\text { gene }\end{array}$ & $\begin{array}{l}\text { Mutagenesis in cassava to } \\
\text { produce target site }\end{array}$ & Dwarf phenotype & {$[55]$} \\
\hline Watermelon & $\begin{array}{l}\text { ClPDS (phytoene } \\
\text { desaturase }\end{array}$ & $\begin{array}{l}\text { For knockout mutations } \\
\text { in Watermelon. }\end{array}$ & $\begin{array}{l}\text { Apparent or mosaic } \\
\text { albino } \\
\text { phenotype }\end{array}$ & [56] \\
\hline $\begin{array}{l}\text { Salvia } \\
\text { miltiorrhiza }\end{array}$ & $\begin{array}{l}\text { Diterpene synthase } \\
\text { gene } \\
(S m C P S 1)\end{array}$ & $\begin{array}{l}\text { For precisely knockout } \\
\text { the SmCPS1 in } S \text {. } \\
\text { miltiorrhiza }\end{array}$ & $\begin{array}{l}\text { The roots of } \\
\text { homozygous mutants } \\
\text { were white in } \\
\text { appearance, whereas } \\
\text { wild-type plants had } \\
\text { red-colored } \\
\text { roots. }\end{array}$ & [57] \\
\hline
\end{tabular}




\begin{tabular}{|c|c|c|c|c|}
\hline Lotus japonicus & $\begin{array}{l}S Y M R K \text { (symbiosis } \\
\text { receptorlike } \\
\text { kinase), LjLbl, } \\
L j L b 2 \text {, and } \\
L j L b 3\end{array}$ & $\begin{array}{l}\text { For effectively target } \\
\text { single } \\
\text { and multiple genes } S N F\end{array}$ & $\begin{array}{l}\text { The triple mutant } \\
\text { produced white } \\
\text { nodules, whereas } \\
\text { control plants } \\
\text { formed pink nodules }\end{array}$ & [23] \\
\hline Vitis vinifera L. & $\begin{array}{l}M L O-7 \quad \text { (Mildew } \\
\text { Locus O) }\end{array}$ & $\begin{array}{l}\text { For tolerance } \\
\text { against powdery mildew }\end{array}$ & $\begin{array}{l}\text { MLO genes are } \\
\text { conserved, and } \\
\text { their loss of function } \\
\text { results in } \\
\text { resistance against } \\
\text { powdery mildew }\end{array}$ & [58] \\
\hline Malus pumila & $\begin{array}{l}D I P M-1, \quad D I P M-2, \\
\text { and } D I P M-4\end{array}$ & $\begin{array}{l}\text { For resistance to } \\
\text { fire blight disease }\end{array}$ & $\begin{array}{l}\text { Physical interaction } \\
\text { with the } \\
\text { disease-specific gene } \\
\text { of Erwinia } \\
\text { amylovora, }\end{array}$ & [59] \\
\hline $\begin{array}{ll}\text { Citrus } & \text { sinensis } \\
\text { Osbeck } & \end{array}$ & $\begin{array}{l}\text { Gene CsLOBI } \\
\text { (LATERAL } \\
\text { ORGAN } \\
\begin{array}{l}\text { BOUNDARIES1) } \\
\quad \text { promoter }\end{array} \\
\end{array}$ & $\begin{array}{l}\text { For tolerance against } \\
\text { citrus canker as with in } \\
\text { wild type }\end{array}$ & $\begin{array}{l}\text { Mutant plants } \\
\text { showed tolerance } \\
\text { against citrus canker }\end{array}$ & {$[60]$} \\
\hline $\begin{array}{l}\text { Citrus paradise } \\
\text { Macf. }\end{array}$ & $\begin{array}{l}\text { CsLOB1 (C. sinensis } \\
\text { Lateral } \\
\text { Organ Boundaries) } \\
\text { gene }\end{array}$ & $\begin{array}{l}\text { For generating canker } \\
\text { resistant } \\
\text { grapefruit }\end{array}$ & $\begin{array}{l}\text { Exhibited canker } \\
\text { symptoms same } \\
\text { as wild type }\end{array}$ & {$[61]$} \\
\hline Musa acuminata & $\begin{array}{l}P D S \quad \text { (phytoene } \\
\text { desatur }\end{array}$ & Basic purpose & $\begin{array}{l}\text { Slower germination } \\
\text { growth on the } \\
\text { selection medium. }\end{array}$ & {$[62]$} \\
\hline $\begin{array}{l}\text { Nicotiana } \\
\text { benthamiana }\end{array}$ & $\begin{array}{l}\text { BeYDV (short } \\
\text { intergenic } \\
\text { region, transacting } \\
\text { replication } \\
\text { initiation protein) }\end{array}$ & $\begin{array}{l}\text { For fight against Leaf } \\
\text { thickening, chlorosis, } \\
\text { curling caused by Bean } \\
\text { yellow dwarf virus } \\
\text { (BeYDV) }\end{array}$ & $\begin{array}{l}87 \% \text { reduction in } \\
\text { targeted viral load. } \\
\text { The study proved that } \\
\text { IR targeting } \\
\text { via sgRNA confer } \\
\text { better resistance }\end{array}$ & {$[63]$} \\
\hline N. benthamiana & $\begin{array}{l}T Y L C V-I R \\
\text { (intergenic regions), } \\
\text { RCA regions }\end{array}$ & $\begin{array}{l}\text { For the defense of Leaf } \\
\text { curl disease }\end{array}$ & $\begin{array}{l}\text { Mutants showed } \\
\text { delayed and } \\
\text { reduced viral DNA } \\
\text { accumulation }\end{array}$ & {$[27,64]$} \\
\hline N. benthamiana & NtPDS and NtPDR6 & $\begin{array}{l}\text { For examination of } \\
\text { transient genome editing } \\
\text { activity and target } \\
\text { mutagenesis }\end{array}$ & $\begin{array}{l}\text { The psd mutant } \\
\text { showed etiolated } \\
\text { leaves, and the pdr6 } \\
\text { mutant } \\
\text { displayed more } \\
\text { branches }\end{array}$ & {$[65]$} \\
\hline N. tabacum L. & $\begin{array}{l}\text { XylT (b }(1,2)- \\
\text { xylosyltransferase) } \\
\text { fucosyltransferase }\end{array}$ & $\begin{array}{l}\text { For the remove plant } \\
\text { type glycans by } \\
\text { inactivation of } \\
\text { those two enzymes }\end{array}$ & $\begin{array}{l}\text { Devoid and strong } \\
\text { reduction of } \\
a(1,3)-\text { fucose and } \\
b(1,2)-x y l o s e\end{array}$ & [66] \\
\hline $\begin{array}{l}\text { N. benthamiana } \\
\text { L. and } \\
\text { Arabidopsis }\end{array}$ & $E D S 1$ and $P A D 4$ & $\begin{array}{l}\text { For induction of } \\
\text { inheritable } \\
\text { chromosomal deletions }\end{array}$ & $\begin{array}{l}\text { EDS1-family genes } \\
\text { are essential } \\
\text { regulators of plant } \\
\text { innate immunity. }\end{array}$ & {$[67]$} \\
\hline $\begin{array}{l}\text { Solanum } \\
\text { lycopersicum L. }\end{array}$ & $\begin{array}{l}\text { SIPDS (phytoene } \\
\text { desaturase) }\end{array}$ & $\begin{array}{l}\text { For targeted mutagenesis } \\
\text { in tomato plants }\end{array}$ & $\begin{array}{l}\text { The mutants of } \\
\text { SIPDS showed an }\end{array}$ & {$[68]$} \\
\hline
\end{tabular}




\begin{tabular}{lllll}
\hline & $\begin{array}{l}\text { and } \\
\text { SIPIF4(phytochrome } \\
\text { interacting factor) }\end{array}$ & & albino phenotype. \\
$\begin{array}{l}\text { S.. lycopersicum } \\
\text { L. }\end{array}$ & $\begin{array}{l}\text { SlIAA9 (auxin- } \\
\text { induced 9) }\end{array}$ & $\begin{array}{l}\text { For parthenocarpic } \\
\text { tomato plants }\end{array}$ & $\begin{array}{l}\text { Morphological } \\
\text { changes in seedless } \\
\text { fruit and leaf shape }\end{array}$ & [69] \\
\hline $\begin{array}{l}\text { Solanum } \\
\text { tuberosum }\end{array}$ & $\begin{array}{l}\text { GBSS (granule- } \\
\text { bound starch }\end{array}$ & $\begin{array}{l}\text { For the starch quality } \\
\text { alter }\end{array}$ & $\begin{array}{l}\text { Reduction of } \\
\text { amylose content in }\end{array}$ & [70] \\
\hline $\begin{array}{l}\text { Cucumis sativus } \\
\text { L. }\end{array}$ & $\begin{array}{l}\text { eIF4E (eukaryotic } \\
\text { translation } \\
\text { initiation factor4E) } \\
\text { gene }\end{array}$ & $\begin{array}{l}\text { For enhance tolerance } \\
\text { against the virus in } \\
\text { Cucumber sativus L. }\end{array}$ & $\begin{array}{l}\text { Enhanced tolerance } \\
\text { against the } \\
\text { infection of Papaya } \\
\text { ringspot mosaic }\end{array}$ & [71] \\
& & & $\begin{array}{l}\text { virus- } \\
\text { W(PRSV-W) }\end{array}$ \\
\hline $\begin{array}{l}\text { Lactuca sativa } \\
\text { LsBIN2 (A. thaliana) }\end{array}$ & $\begin{array}{l}\text { For DNA-free genome } \\
\text { editing }\end{array}$ & $\begin{array}{l}\text { Calli contained } \\
\text { monoallelic and } \\
\text { biallelic mutations }\end{array}$ \\
\hline
\end{tabular}

\section{Supremacy of CRISPR/Cas9 technology}

The simplicity, highly reliable and validity for CRISPR/cas9 as new gene editing tool is improved the gene editing methods as genomic scale the advantage of the CRISPR/Cas9 engineered has been noted in different accepts $[57,58]$. Versatile and comparatively precise approach innovation of misused for the specific guide RNA to make the new generation yield plants using the tricky infection and host interpretation factors. In other, CRISPR/Cas9 is wide noted frameworks among the accessible gene. With the incredible contribute the sustainable farming without biotic and abiotic effect by modify the specific DNA sequence. The valuable and remarkable advantage is to minimize the target activity and double nicking strategy which the target site of the genome. CRISPR/Cas9 has success rate according the species nature for nutritional value, stress control and improvement of crop is increased [33]. Multiple gene disruption is defined from the CRISPR/Cas9 technology which allow the researcher for editing the target site of DNA to edit the multiple genes in one line of plant [11]. Which is beneficial for the time and economy. The new instrument CRISPR/Cas9 has widely used in the world due to the easy handling as well as minimize cost for the genome engineering. This is revolution of the 
biological sciences whether used in human, animals and plants. In plant mostly used for disease resistance verity and as well as crop improvement. Older technology ZFNs and TALENs, are slow and less reliable then CRISPR/ Cas9 as well as expensive for finding the target DNA engineered [44].

\section{Future of CRISPR/Cas9 in plants}

The CRISPR/Cas9 is mostly used friendly and easily with the designer nuclease system. Currently precision for the genome engineered system, medicinal plants have changed the DNA sequences for the instant the DNA sequences changed from the CRISPR/Cas9 technology helps to reduce the toxic components present in plants. The system of CRISPR/ Cas9 is challenges and highly applicable for the different purposes in the plants. The molecular scissor CRISPR/Cas9 for the revolution in biological science, and the world has been changed for the easiest DNA engineered. The most significance changes are to permit absolutely and surprising heredity changes from the gRNAs with Cas9 [59]. Instead of the CRISPR/Cas9 instrument is magnificent apparatus for the genome engineering. It is necessary to investigate the off-target changes effectiveness with in the coordinate target site. In future phyto-pathogenic infection would be harmful then would be improvement of exact cut sequence site of DNA.

The coming research will go the ideal and advanced and hope the quality of success in soon. The quality of the gene editing has been completely changed from the CRISPR/Cas9. Analyzing and investigation of primary research which will be minimized from the abiotic and biotic stress burden. More research remains to improve the plants. The CRISPR/Cas 9 is being a lightening eyes for the designer plants will be interest for the wild type plants and preserve the extended plants through the microspore. CRISPR/Cas9 is highly used for the genome biology. The 
CRISPR/Cas9 will boost the future desired mutation of the plants for modify the eukaryotic and prokaryotic genome.

\section{Conclusion}

Amazing instrument CRISPR/Cas9 in plants due to its significant, off-target impact, easy to handle, proficiency for the mutagenesis in comparison of ZFNs and TALENs. This system is revalidation and achieved benefit progress to increase the efficiency of the target site. It gives the new approach for the high yield with improved verities. This technology being advanced, and the gene is real changes. The alternation incorporation substitution, cancellations, reversal, knockouts, and translocations. Newly emerged technology evaded need to rely on the target specific gene. The plant from the CRISPR/Cas9 has no exogenous DNA and can be accepted from the changed sequence. Furthermore DNA laves and epigenetic editing with the CRISPR/Cas9 [73, 74].

Genetic engineering, abiotic stress resistance, phytoremediation contributes the incredibly without the doughty CRISPR/Cas9 system can promote the genome adjustment in yield of crops. Particularly increased and decrease the impact of the previous sequence of DNA should be involved in gRNA/Cas9 complex. This will modify the novel allele's improvement of the plants as a tricky infections utilization of the host part. Another remarkable property of the CRISPR/Cas9 technology to produce the new opposition alleles from the genome altering process for the boosting yield controlling through the abiotic and biotic stress in environment.

DNA focused close to the PAM site due to gRNA and Cas9 by communicate and built the sequence of DNA. Double stranded break (DSB) can fixed by the non-homologous end joining (NHEJ) or homology coordinated fix (HCF). Fix of NHEJ move to change quality of Knockout that given DNA end homology. The point can be embedded at the focused y to adjust a quality by 
including changes in nucleotides or by quality inclusion [3]. Individual trRNA and crRNA is less effective than that of combined sgRNA and Cas9 complex. Homology directed repair from the exact substitution mutation [32].

Although the CRISPR/Cas9 can be applied for genome editing in plant. For the reliable plant genetic editing need to certain changes for minimizing the target rate, elucidate the mechanism and for how will be optimize the editing percentage. Further research need to improve the CRISPR/Cas9 for basic and applied requirement in future.

Author contributions: Conceptualization, N.P. writing original draft preparation, funding acquisition S.P.; Y. J., S.R. and S.P. revised and editing. All authors have read and agreed to publish version of the manuscript.

Funding: This research was funded by National Institute of Horticultural and Herbal Science, Rural Development Administration, Republic of Korea (Project No. PJ0148292021).

\section{Acknowledgments}

We thank all members of the vegetable division for helpful and constructive discussion

Conflict of interest: The authors declare that they have no conflict of interest.

\section{References}

1. Song, G.; Jia, M.; Chen, K.; Kong, X.; Khattak, B.; Xie, C.; Li, A.; Mao, L. CRISPR/Cas9: A powerful tool for crop genome editing. Crop J. 2016, 4, 75-82. 
2. Jinek, M.; chylinski, K.; Fonfara, I.; Hauer, M.; Doudna, J. A.; Charpentier, E.; 2012. A programmable dual- RNA - guided DNA endonuclease in adoptive bacterial immunity. Science. 2012, 337, 816- 821.

3. Cong, L.; Ran, F.; A.; Cox, D.; Lin, S.; Barretto, R.; Habib, N.; Hsu, P.D.; Wu, X.; Jiang, W.; Marraffini, L.A.; Zang F.. Multiplex genome engineering using CRISPR/Cas system, Science. 2013. 339, 819-823.

4. Mali, P.; Yang, L.; Esvelt, K. M.; Aach, J.; Guell, M.; dicarlo, J. E.; Norville, I. E.; Church, G. M. RNA-guided human genome engineering via cas9. Science. 2013, 339, 823826.

5. Huang, H.; Cui, T.; Zhnag, L.; Yang, Q.; Yang, Y.; Xie, K; Fan, C.; Zhou,, Y. Modification of fatty acid profile through targeted mutation at BnaFAD2 gene with CRISPR/Cas9- medicated gene editing in Brassica napus. Theor. Appl. Geneti. 2020, 133, 2401-2411.

6. Wolabu , T.W.; Park, J.J.; Chen, M.; Chag ,L.; Ge, Y.; Jiang, U, Debnath S.; Li, G.; Wen, J.; Wang, Z Improving the genome editing efficiency of CRISPR/Cas9 in Arbiodopsis and Medicago trucatula . 2020, 252, 1-15.

7. Hunter, M.C.; Smith, R.G.; Schipanski, M.E.; Atwood, L.W.; Mortensen, D.A. Agriculture in 2050: recalibrating targets for sustainable intensification. Bio Science, 2017, 67, 385-390.

8. Bhowmik, P.; Ellison, E.; Polley, B.; Bollina, V.; Kulkarni, M.; Ghanbarnia, K.; Song, H.; Gao, C.G.; Voytas, D.F.; Kagale, S. Targeted mutagenesis in wheat microspores using CRISPR/Cas9. Sci. Rep. 2018, 8, 6502. 
9. Liu, X.; Wu, S.; Xu, J.; Sui, C.; Wei, J.Application of CRISPR/Cas9 in plant biology. Acta Pharma. sin B. 2017, 7(3), 292-302.

10. Belhaj, K.; Chaparro-Garcia, A.; Kamoun, S.; Patron, N.J.; Nekrasov, V.; Editing plant genomes with CRISPR/Cas9. Curr Opin. Biotechnol. 2015, 32, 76-84.

11. Khott, G. J.; Doudha, J.A. CRISPR-Cas guides the future of genetic engineering. Science. 2018, 361(6405), 866-869.

12. Mohanta, T.K.; Bashir, T.; Hshem, A.; Allah, E.F.A.; Bae, H. Genome editing tools in plants. Genes. 2017, 8(12), 399.

13. Brouns, S.J.J.; Jore, M.M.; Ludgren, M.; Westra, E.R.; Sliijkuis, R.J.H.; Snijders, A.P.; Dickmen, M.J.; Makarova, K.S.; Koonin, E.V.; Vande Oost, J. small CRISPR RNAs guide antiviral defense in prokaryotes. Science. 2008, 321(5891), 960-964.

14. Maher, M. F.; Nasti, R. A.; Vollbrecht, M.; Starker, C. G.; Clark, M. D.; Voytas, D. F. Plant gene editing through de novco induction of meristems . Nat. biotechnol. 2020, 38, 84-89.

15. Melchers, L.S.; Stuiver, M.H. Novel genes for disease-resistance breeding .Curr. Opin Plant Biol. 2000, 3(2), 147-152.

16. Van den Bulk, R.W. Application of cell and tissue culture and in vitro selection for disease resistance breeding - a review. Euphytica, 1991, 56(3): 269-285.

17. Kumar, V.; Jain, H. The CRISPR-Cas system for genome editing: advances and opportunities. J Exp Bot. 2015, 66(1), 47-57.

18. Makarova, K.S.; Haft, D.H.; Barrangou, R.; Brouns, S.J.J.; Charpentier, E.; Horvath, P.; Moineau, S.; Mojica, F.J.M.; Wolf, Y.I.; Yakunin, A.F.; Oost, J.V.D.; Koonin, E.V. 
Evolution and classification of the CRISPR-Cas systems. Nat. Rev. Microbiol. 2011, 9, 467-477.

19. Makarova, K.S.; Wolf, Y.I.; Alkhnbashi, O.S.; Costa, F.; Shah, S.A.; Saunders, S.J.gou, R.; Brouns, S.J.J.; Charpentier, E.; Haft, D.H.; Hovath, P.; Sylvain, M.; Mojica, F.J.M.; Terns, R.M.; Trens, M.P.; White, M.F.; Yakunin, A.F.; Garrett, R.A. Oost, J.; Backofen, R.; Koonin, E.V. An updated evolutionary classification of CRISPR-Cas systems. Nat. Rev. Microbiol. 2015, 13, 722-736.

20. Sternberg, S. H.; LaFrance, B.; Kaplan. M.; Doudna, J. A. Conformational control of DNA target cleavage by CRISPR Cas9. Nature, 2015, 527(7576), 110.

21. Singh, D.; Sternberg, S. H.; Fei, J.; Doudna, J. A.; Ha. Real-time observation of DNA recognition and rejection by the RNA-guided endonucleaseCas9. Nat. commun. 2016, 7, 12778.

22. Garneau, J.E.; Dupuis, M.E.; Villion, M.; Romero, D.A.; Barrangou, R.; Boyaval, P.; Freaux, C.; Horvath, P.; Magadan, A.H.; Moineau, S. The CRISPR/cas bacterial immune system cleaves bacteriophage and plasmid DNA. Nature. 2010, 468, 67-71.

23. Wang, H.; La Russa, M.; Qi, L.S. CRISPR/Cas9 in genome editing and beyond. Ann Rev biochem. 2016, 85, 227-264.

24. Bhaya, D.; Davison, M.; Barrangou, R. CRISPR-Cas systems in bacteria and archaea: versatile small RNAs foradaptive defense and regulation. Ann Rev genet. 2011, 45, 273297.

25. Chaparro-Garcia, A.; Kamoun,S.; Nekrasov, V. Boosting plant immunity with CRISPR/Cas. Genome boil.. 2015, 16(1): 254. 
26. Jiang, W.; Zhou, H.; Bi, H.; Fromm, M.; Yang, B.; Weeks, D.P. Demonstration of CRISPR/Cas9/sgRNA-mediated targeted gene modification in Arabidopsis, tobacco, sorghum and rice. Nucleic acids Res. 2013, 41(20): e188-e188.

27. Ali, Z.; Abulfaraj, A.; Idris, A.; Ali, S.; Tashkandi, M.;Mahfouz, M.M. CRISPR/Cas9mediated viral interference in plants. Genome boil. .2015, 6(1), 238.

28. Baltes, N.J.; Hummel, A.W.; Konecna, E.; Cegan, R.; Bruns, A.N.; Bisaro, D.M.; Voytas, D.F.; Conferring resistance to geminiviruses with the CRISPR-Cas prokaryotic immune system. Nat. Plant. 2015, 1, 15145.

29. Ji, X.; Zhang, H.; Zhang, Y.; Wang, Y.; Gao, C. Establishing a CRISPR-Cas-like immune system conferring DNA virus resistance in plants. Nat. Plants. 2015, 1: 15144. 30. Puchta, H.; Fauser, F. Gene targeting in plants: 25 years later. Int J Dev Biol. 2013, 57, 629-637.

31. Doudna, J.; Charpentier, E. Genome editing .The new frontier of genome engineering with CRISPR-Cas9. Science. 2014, 346(6213), 1258096.

32. Strenberg, S.H.; Redding,S.; Jinek, M.; Greene, E.C.; Doudra, J.A. DNA interrogation by the CRISPR RNA-guided endonuclease Cas9. Nature. 2014, 507(7490), 62-67.

33. Zhang, L.L.; Zhou, Q. CRISPR/Cas technology: a revolutionary approach for genome engineering. Sci China Life Sci. 2014, 57(6), 639-640.

34. Khatodia,S.; bhatoia, K.; Passricha, N.; Khurana, S.M.; Tuteju, N. The CRISPR/Cas genome- editing tool: application in improvement of crops. Front. plant Sci. 2016, 7, 506. 35. Xu, H.; Xiao, T.; Chen, C.H.; Li, W.; Meyer, C.A.; Wu, Q.; Wu, D.; Cong, L.; Zhang, F.; Liu, J.S.; Brown, M.; Liu, X.S. Sequence determinants of improved CRISPR sgRNA design. Genome Res. 2015, 1147-1157. 
36. Li, Z.; Liu, Z.B.; Xing, A.; Moon, B.P.;Koellhoffer, J.P.; Huang, L.; Ward, R.T.;Clifton, E.; Falco, S.C.;Cigan, A.M. Cas9-guide RNA directed genome editing in Soybean. Plant Physiol. 2015, 169(2), 960-970.

37. Girud, T.; Gladieux, P.; Gavrilets, S. Linking the emergence of fungal plant disease with ecological speciation. Trends Ecol Evol. 2010, 25, 387-395.

38. Seo, Y.S.; Lim, J.Y.; Park, J.; Kim, S.; Lee, H.H.; Cheong, H Kim, S>M.; Moon, J.S.; Hwang, I. Comparative genome analysis of rice-pathogenic Burkholderia provides insight into capacity to adopt to different enviroments and hosts. BMC Genom. 2015, 16, 349.

39. Wang, Y.; Cheng, X.; Shan, Q.; Zhang, Y.; Liu, J.; Gao, C.; Qiu, J.L. Simultaneous editing of three homoeoalleles in hexaploid bread wheat confers heritable resistance to powdery mildew. Nat. Biotech. 2014, 32, 947-951.

40. Richeter, C.;Gristwood, T.; Clulow, J.S.; Fineran, C.P. In vivo protein interactions and complex formation in the pectobacterium astrosepticum subtype I-F CRISPR/Cas system. PLos ONE. 2012, 7(12), e49549.

41. Jia , H.; Wang, N. Targeted genome editing of sweet orange using Cas9/sgRNA. PLos ONE. 2014, 9(4), e93806.

42. Zhou, H.; He, M.; Li, J.; Chen, L.; Huang, Z.; Zheng, S.; Zhu, L.,;Ni, E.; Jiang, B.Z.; Zhuang, C. Development of commercial thermo-sensitive genic male sterile rice accelerates hybrid rice breeding using the CRISPR/Cas9-mediated TMS5 editing system. Sci Rep. 2016, 6, 37395.

43. Sun, Y.;Zhang, X.; Wu, C.; He, Y.; Ma, Y.; Hou, H.; Guo, X.; Du, W.;Zhao, Y.; Xia, L. Engineering herbicide-resistant rice plants through CRISPR/Cas9-mediated homologous recombination of acetolactate synthase. Mol Plant, 2016, 9(4), 628-631. 
44. Liang, Z.; Chen, K.; Li, T.; Zhang, Y.; Wang, Y.; Zhao, Q.; Liu, J.; Zhang, H.; Liu, C.; Ran, Y.; Gao, C. Efficient DNA-freegenome editing of bread wheat using CRISPR/Cas9 ribonucleoprotein complexes. Nat. Commun.2017, 8, 14261.

45. Chen, X.; Lu, X.; Shu, N.; Wang, S.; Wang, J.; Wang, D.; Guo, L.; Ye, W. Targeted mutagenesis in cotton (Gossypium hirsutum L.) using the CRISPR/Cas9 system. Sci. Rep. 2017, 7, 44304 .

46. Wang, P.; Zhang, J.; Sun, L.; Ma, Y.; Xu, J.; Liang, S.; Deng, J.; Tan, J.; Zhang, Q.; Tu, L.; Daniell, H.; Jin, S.; Zhang, X .High efficient multisite genome editing in allotetraploid cotton (Gossypium hirsutum) using the CRISPR/Cas9 system. Plant Biotechnol J. 2018, 16(1), 137-150.

47. Li, C.; Unver, T.; Zhang, B. A high-efficiency CRISPR/Cas9 system for targeted mutagenesis in Cotton (Gossypium hirsutum L.). Sci. Rep. 2017, 7, 43902.

48. Char, S.N.; Neelakandan, A.K.; Nahampun, H.; Frame, B.; Main, M.; Spalding, M.H.; Becraft, P.W.; Meyers, B.C.; Walbot, V.;Wang, K.; Yang, B. An Agrobacterium-delivered CRISPR/Cas9 system for high-frequency targeted mutagenesis in maize. Plant Biotechnol J. 2017, 15(2), 257-268.

49. Kanazashi, Y.; Hirose, A.; Takahashi, I.; Mikami, M.; Endo, M.; Hirose, S.; Toki, S.; Kaga, A.; Naito, K.; Ishimoto, M.; Abe, J.; Yamada, T. Simultaneous site-directed mutagenesis of duplicated loci in soybean using a single guide RNA. Plant Cell Rep. 2018, 37, 553-563.

50. Cai, Y.; Chen, L.; Liu, X.; Guo, C.; Sun, S.; Wu, C.; Jiang, B.; Han, T.; Hou, W. CRISPR/Cas9-mediated targeted mutagenesis of GmFT2a delays flowering time in soyabean. Plant Biotechnol J. 2018, 16(1), 176-185. 
51. Li, A.; Jia, S.; Yobi, A.; Ge, Z.; Sato, S.J.; Zhang, C.; Angelovici, R.; Clemente, T.E.; Holding, D.R. Editing of an alphakafirin gene family increases, digestibility and protein quality in sorghum. Plant Physiol.2018, 177(4), 1425-1438.

52. Lawrenson, T.; Shorinola, O.; Stacey, N.; Li, C.; Østergaard, L.; Patron, N.; Uauy, C.; Harwood, W.. Induction of targeted, heritable mutations in barley and Brassica oleracea using RNA-guided Cas9 nuclease. Genome Biology, 2015, 16, 258.

53. Yang, H.; Wu, J.J.; Tang, T.; Liu, K.D.; Dai, C. CRISPR/Cas9-mediated genome editing efficiently creates specific mutations at multiple loci using one sgRNA in Brassica napus. Sci. Rep. 2017, 7(1), 7489.

54. Li, C.; Chen, C.; Chen, H., Wang, S.; Chen, X.; Cui, Y. Verification of DNA motifs in Arabidopsis using CRISPR/Cas9-mediated mutagenesis. Plant Biotechnol J. 2018, 16(8), 1446-1451.

55. Odipio, J.; Alicai, T.; Ingelbrecht, I.; Nusinow, D.A.; Bart, R.; Taylor, N.J. Efficient CRISPR/Cas9genome editing of phytoene desaturase in cassava. Front. Plant Science, 2017, 8, 1780 .

56. Tian, S.; Jiang, L.; Gao, Q.; Zhang, J.; Zong, M., Zhang, H.; Ren, Y.; Guo, S.; Gong, G.; Liu, F.; Xu, Y. Efficient CRISPR/Cas9-based gene knockout in watermelon. Plant Cell Rep. 2017, 36(3), 399-406.

57. Li, B.; Cui, G.; Shen, G.; Zhan, Z.; Huang, L.; Chen, J.; Qi, X. Targeted mutagenesis in the medicinal plant Salvia miltiorrhiza. Sci. Rep. 2017, 7, 43320.

58. Malnoy, M.; Viola, R.; Jung, M.H.; Koo, O.J.; Kim, S.; Kim, J.S.; Velasco, R.; Nagamangala, K.C. DNA-free genetically edited grapevine and apple protoplast using CRISPR/Cas9 ribonucleoproteins. Front. Plant Sci. 2016, 7, 1904. 
59. Pessina, S.; Lenzi, L.; Perazzolli, M.; Manuela, C.; Lorenza, D.C.; Simona, U.; Giampiero, V.; Francesco, S.; Riccardo, V. Mickael, M. Knockdown of $M L O$ genes reduces susceptibility to powdery mildew in grapevine. Hortic. Res. 2016, 3, 16016.

60. Peng, A.; Chen, S.; Lei, T.; Xu, L., He.; Y.;Wu, L.; Yao, L.; Zou, X. Engineering canker-resistant plants through CRISPR/Cas9-targeted editing of the susceptibility gene CsLOB1 promoter in citrus. Plant Biotechnol J .2017, 15(12), 1509-1519.

61. Jia, H.; Orbovic, V.; Jones, J.B.; Wang, N. Modification of the PthA4effector binding elements in type I CsLOB1promoter using Cas9/sg RNA to produce transgenic Duncan grapefruit alleviatingXccDpthA4:dCsLOB1.3 infection. Plant Biotechnol J. 2016, 14, 1291-1301.

62. Kaur, N.; Alok, A.; Shivani, K. N.; Pandey, P.; Awasthi, P.; Tiwari, S. CRISPR/Cas9mediated efficient editing in phytoene desaturase (PDS) demonstrates precise manipulation in banana cv. Rasthali genome. Funt. Integr. Genomics. 2018, 18(1), 89-99.

63. Baltes, N.J.; Gil-Humanes, J.; Cermak, T.; Atkins, P.A.; Voytas, D.F. DNA replicons for plant genome engineering. Plant Cell. 2014, 26, 151-163.

64. Ali, Z.; Ali, S.; Tashkandi, M.; Zaidi, S.S.; Mahfouz, M.M. CRISPR/Cas9-mediated immunity to geminiviruses: Differential interference and evasion. Sci. Rep. 2016, 6, 26912. 65. Gao, Y.; Zhang, Y.; Zhang, D.; Dai, X.; Estelle, M.; Zhao, Y. Auxin binding protein 1 (ABP1) is not required for either auxin signaling or Arabidopsis development. Proceedings of National Academy of Sciences.USA. 2015, 112 (7), 2275-2280.

66. Mercx, S.; Smargiasso, N.; Chaumont, F.; De Pauw, E.; Boutry, M.; Navarre, C. Inactivation of the $\beta(1,2)$-xylosyltransferase and the $\alpha(1,3)$-fucosyltransferase genes in 
Nicotiana tabacum BY-2 Cells by a Multiplex CRISPR/Cas9 Strategy Results in glycoproteins without plant-specific glycans. Front. Plant Sci. 2017, 8, 403.

67. Ordon, J.; Gantner, J.; Kemna, J.; Schwalgun, L.; Reschke, M.;Streubel, J.; Boch, J.; Stuttmann, J.; Generation of chromosomal deletions in dicotyledonous plants employing a user-friendly genome editing toolkit. Plant J. 2017, 89(1), 155-168.

68. Pan, C.; Ye, L.; Qin, L.; Liu, X.; He, Y.; Wang, J.; Chen, L.; Lu, G. CRISPR/Cas9mediated efficient and heritable targeted mutagenesis in tomato plants in the first and later generations. Sci. Rep. 2016, 6, 24765.

69. Ueta, R.; Abe, C.; Watanabe, T.; Sugano, S.S.; Ishihara, R.; Ezura, H.; Osakabe, Y.; Osakabe, K. Rapid breeding of parthenocarpic tomato plants using CRISPR/Cas9. Sci. Rep. 2017, 7, 507.

70. Andersson, M.; Turesson, H.; Nicolia, A.; Fält, A.S.; Samuelsson, M.; Hofvander, P. Efficient, targeted multiallelic mutagenesis in tetraploid potato (Solanum tuberosum) by transient CRISPR-Cas9 expression in protoplasts. Plant Cell Rep. 2017, 36(1), 117-128.

71. Chandrasekaran, J.; Brumin, M.; Wolf, D.; Leibman, D.; Klap, C.; Pearlsman, M. Sherman, A.; Arazi, T.; On, A. G. Development of broad virus resistance in non-transgenic cucumber using CRISPR/Cas9 technology. Mol Plant Pathol.2016, 17, 1140-1153.

72. Woo, J.W.; Kim, J.; Kwon, S.I.; Corvalán, C.; Cho, S.W.; Kim, H. Kim, S.G.; Kim, S.T.; Choe, S.; Kim J.S. DNA-free genome editing in plants with preassembled CRISPRCas9 ribonucleoproteins. Nat. Biotechnol. 2015, 33(11), 1162-1164.

73. Ma, H.H; Tu, L.C.; Naseri, A.; Huisman, M.; Zhang, S.J.; Grunwald, D.; Pederson T. Multiplexed labeling of genomic loci with dCas9 and engineered sgRNAs using CRISPRainbow. Nat Biotechnol 2016, 34:528-30. 
74. Hilton, I.B. D.; Ippolito A. M.; Vockley , C.M.; Thakore, P.L.; Crawford, G.E.; Reddy, T. E.; Gerbach, C.A. Epigenome editing by a CRISPR-Cas9 based acetyl transfer activate genes from promoters and enhancers. Nat. Biotechnol. 2015, 33,510-517. 